\title{
A selected list of the published writings of Tracy M. Sonneborn
}

The following references, compiled from among 216 publications to date, have been selected as representative of the breadth and productivity of Sonneborn's career. It should be noted that many of his important discoveries have been announced solely in abstracts.

Sonneborn, T. M. (1930). Genetic studies on Stenostomum incaudatum (nov. spec.). I. The nature and origin of differences among individuals formed during vegetative reproduction. Journal of Experimental Zoology 57, 57-108.

Sonseborn, T. M. (1930). Genetic studies on Stenostomum incaudatum. II. The effects of lead acetate on hereditary constitution. Journal of Experimental Zoology 57, 409-439.

Sonnebonn, T. M. (1931). McDougall's Lamarckian experiment. American Naturalist 65, $541-550$.

Sonneborn, T. M. (1932). Experimental production of chains and its genetic consequences in the ciliate protozoan Colpidium campylum. Biological Bulletin 63, 187-211.

SONNEBoRn, T. M. \& LYNCH, R.S. (1932). Racial differences in the early physiological effects of conjugation in Paramecium aurelia. Biological Bulletin 62, 258-293.

SonNeborN, T. M. \& LYNCH, R. S. (1934). Hybridization and segregation in Paramecium aurelia. Journal of Experimental Zoology 67, 1-72.

SONNEBorN, T. M. (1937). Sex, sex inheritance and sex determination in Paramecium aurelia. Proceedings of the National Academy of Sciences, U.S.A. 23, 378-385.

SonNeborn, T. M. (1938). Mating types in Paramecium aurelia: diverse conditions for mating in different stocks; occurrence, number and interrelations of the types. Proceedings of the American Philosophical Society 79 411-434.

Sonneborn, T. M. (1939). Paramecium aurelia : mating types and groups; lethal interactions; determination and inheritance. American Naturalist 73, 390-413.

SonNebork, T. M. (1942). Inheritance in ciliate protozoa. American Naturalist 76, 46-62.

SonneborN, T. M. \& Dippell, R. V. (1943). Sexual isolation, mating types, and sexual responses to diverse conditions in variety 4, Paramecium aurelia. Biological Bulletin 85 , $36-43$.

SonNeborn, T. M. (1943). Gene and cytoplasm. T. The determination and inheritance of the killer character in variety 4 of Paramecium aurelia. Proceedings of the National Academy of Sciences, U.S.A. 29, 329-338.

Sonneborn, T. M. (1943). Gene and cytoplasm. II. The bearing of the determination and inheritance of characters in Paramecium aurelia on the problems of cytoplasmic inheritance, pneumococcus transformations, mutations and development. Proceedings of the National Academy of Sciences, U.S.A. 29, 338-343.

Sonneborn, T. M. (1945). The dependence of the physiological action of a gene on a primer and the relation of primer to gene. American Naturalist 79, 318-339.

SonneborN, T. M. \& Dippell, R. V. (1946). Mating reactions and conjugation between varieties of Paramecium aurelia in relation to conceptions of mating type and variety. Physiological Zoology 19, 1-18.

SonNeborn, T. M. (1946). Experimental control of the concentration of cytoplasmic genetic factors in Paramecium. Cold Spring Harbor Symposium on Quantitative Biology 11, 236-255.

Sonnebori, T. M. (1947). Recent advances in the genetics of Paramecium and Euplotes. Advances in Genetics 1, 264-358.

Sonneborn, T. M. (1947). Developmental mechanisms in Paramecium. Grouth Symposium. 11, 291-307.

SonNEBorn, T. M. (1948). The determination of hereditary antigenic differences in genically identical Paramecium cells. Proceedings of the National Academy of Sciences, U.S.A. 34,413418 . 
Sonneborn, T. M. \& LeSuer, A. (1948). Antigenic characters in Paramecium aurelia (variety 4): determination, inheritance and induced mutations. American Naturalist 82, 69-78.

Sonneborn, T. M. (1949). Beyond the gene. American Scientist, 37, 33-59.

Sonneborn, T. M. (1949). Ciliated protozoa: cytogenetics, genetics, and evolution. Annual Review of Microbiology, pp. 55-80.

Sonneborn, T. M. (1950). Methods in the general biology and genetics of Paramecium aurelia. Journal of Experimental Zoology 113, 87-148.

SonNeborn, T. M. (1950). The cytoplasm in heredity. Heredity 4, 11-36.

Sonneborn, T. M. (1950). Heredity, environment, and politics. Science 111 (2890): 529539.

Sonneborn, T. M. (1950). Cellular transformation. Harvey Lecture Series 44, 145-164.

Sonneborn, T. M. (1951). The role of the gene in cytoplasmic inheritance. Chapter 14 of Genetics in the 20th Century (ed. by L. C. Dunn). New York: MacMillan.

SonNeBorn, T. M. (1951). Some current problems of genetics in the light of investigations on Chlamydomonas and Paramecium. Cold Spring Harbor Symposium on Quantitative Biology 16, 483-503.

Sonneborn, T. M. (1952). Problems of tumors in relation to studies on Paramecium. Proceedings of the IInd National Cancer Conference, pp. 1139-1147.

SonNeborn, T. M. (1954). The relation of autogamy to senescence and rejuvenescence in Paramecium aurelia. Journal of Protozoology 1, 38-53.

Sonneborn, T. M. (1954). Patterns of nucleocytoplasmic integration in Paramecium. Caryologia, vol. suppl., pp. 307-325.

Sonneborn, T. M. (1955). Heredity, development and evolution in Paramecium. Nature 175, 1100.

SONNEBORN, T. M. (1957). Breeding systems, reproductive methods, and species problems in Protozoa. In The Species Problem (ed. by E. Mayr), pp. 155-324. American Association for the Advancement of Science.

Sonneborn, T. M. (1960). The gene and cell differentiation. Proceedings of the National Academy of Sciences, U.S.A. 46, 149-165.

SonNeBorn, T. M. (1960). Some comments on the general biological situation with regard to aging. In The Biology of Aging (ed. by B. L. Strehler), pp. 279-280. American Institute of Biological Sciences, publication no. 60.

Sonneborn, T. M. (1960). Tests and critique of some theories of aging. In The Biology of Aging (ed. by B. L. Strehler), pp. 281-282 American Institute of Biological Sciences.

Sonneborn, T. M. \& Dippell, R. V. (1960). Cellular changes with age in Paramecium. In The Biology of Aging (ed. by B. L. Strehler), pp. 285, American Institute of Biological Sciences.

Sonneborn, T. M. \& Schneller, M. V. (1960). Age-induced mutations in Paramecium. In The Biology of Aging (ed. by B. L. Strehler), pp. 286-287. American Institute of Biological Sciences.

SONNEBORN, 'T. M. (1960). The human early foetal death rate in relation to age of father. In The Biology of Aging (ed. by B. L. Strehler), p. 288, American Institute of Biological Sciences.

SONNEBORN, T. M. (1960). Enormous differences in length of life of closely related ciliates and their significance. In The Biology of Aging (ed. by B. L. Strehler), p. 289, American Institute of Biological Sciences.

SonNeborn, T. M. \& Schneller, M. V. (1960). Measures of the rate and amount of aging on the cellular level. In The Biology of Aging (ed. by B. L. Strehler), pp. 290-291, American Institute of Biological Sciences.

Sonneborn, T. M. \& Schnelder, M. V. (1960). Physiological basis of aging in Paramecium. In The Biology of Aging (ed. by B. L. Strehler), pp. 283-284, American Institute of Biological Sciences.

SONNEBORN, T. M. (1963). Does preformed cell structure play an essential role in cell heredity? In The Nature of Biological Diversity (ed. by J. M. Allen), pp. 165-221. New York: MeGraw-Hill.

SonNeborn, T. M. (1963). Implications of the new genetics for biology and man. American Institute of Biological Sciences Bulletin 13, 22-26.

SonNeborn, T. M. (1963). Bearing of protozoan studies on current theory of genic and cytoplasmic action. Praceedings XVIth International Congress of Zoology 3, 197-202. 
Sonneborn, T. M. (1964). The differentiation of cells. Proceedings of the National Academy of Sciences, U.S.A. 51, 915-929.

SonNeborN, T. M. (1965). Degeneracy of the genetic code: extent, nature and genetic implication. In Evolving Genes and Proteins (ed. by V. Bryson and H. J. Vogel), pp. 377-397. New York: Academic Press.

SonNeborn, T. M. (1965). Editor of The Control of Human Heredity and Evolution. New York: Macmillan Company.

Bersson, J. and SonNeBorn, T. M. (1965). Cytoplasmic inheritance of the organization of the cell cortex in Paramecium aurelia. Proceedings of the National Academy of Sciences, U.S.A. 53, 275-282.

SonNeborn, T. M. (1965). Nucleotide sequence of a gene: first complete specification. Science 148 (3676), 1410 .

Sonnebonn, T. M. (1965). Genetics and man's vision. Proceedings of the American Philosophical Society 109, 237-241.

Sonneborn, T. M. (1965). The metagon: RNA and cytoplasmic inheritance. American Naturalist 46 (907), 279- 307.

Sonneborn, T. M. (1966). Genetics of the protozoa. Genetika 11, 31-41.

SonNEBoRn, T. M. (1966). Models for somatic cell variation based on studies of ciliate protozoa. Proceedings of the Mendel Centennial Celebration, Czechoslovakian Academy of Science, Prague, Genetic Variations in Somatic Cells, pp. 87-97.

SonNeBorn, T. M. (1967). The evolutionary integration of the genetic material into genetic systems. Chapter 19 of Heritage from Mendel (ed. by R. A. Brink), pp. 375-402. Madison, Wisconsin: University of Wisconsin Press.

Sonneborn, T. M. (1969). Man's choices. In Genetic Engineering (ed. by D. Paterson), BBC Publication.

Sonneborn, T. M. (1970). Methods in paramecium research. In Methods of Cell Physiology, vol. 4 (ed. by D. M. Prescott), pp. 241-339. New York and London: Academic Press.

Sonneborn, T. M. (1970). Gene action in development. Proceedings of the Royal Society (London) B 176, 347-366.

SonNeborn, T. M. (1973). Ethical issues arising from the possible uses of genetic knowledge. In Ethical Issues in Human Genetics (ed. by B. Hilton, D. Callahan, M. Harris, P. Condliffe and B. Berkley), pp. 1-6. New York and London: Plenum Press.

SoNNEBORN, T. M. (1974). Ciliate morphogenesis and its bearing on general cellular morphogenesis. Actualités Protozoologiques, vol. I (ed. by P. De Puytorac and J. Grain), pp. 337-355. Résumé des discussions des tables rondes du 4th Congress International de Protozoologie, Clermont-Ferrand, France, 1973.

SonNeborn, T. M. (1974). Tetrahymena pyriformis. In Handbook of Genetics, vol. 2 (ed. by R. C. King), pp. 433-467. Now York and London: Plenum Press.

Sonneborn, T. M. (1974). Paramecium aurelia. In Handbook of Genetics, vol. 2 (ed. by R. C. King), pp. 469-594. New York and London: Plenum Press.

Sonneborn, T. M. (1975). The Paramecium aurelia complex of fourteen sibling species. Transactions of the American Microscopial Society 94, 155-178.

SonNeborN, T. M. (1975). Cell differentiation and communication: patterns, problems and probes. Microbiology (in the Press). 